\title{
Linking Abusive Supervision to Employees' OCBs and Turnover Intentions: The role of a Psychological Contract Breach and Perceived Organisational Support
}

\author{
Ezaz Ahmed \\ Central Queensland University \\ E-Mail: e.ahmed@cqu.edu.au \\ Michael Muchiri \\ RMIT University, Melbourne, Australia \\ E-Mail: michael.muchiri@rmit.edu.au
}

\begin{abstract}
This conceptual paper proposes pathways through which abusive supervisor behaviour influences employee outcomes. Specifically, we propose that abusive supervision will directly influence employee citizenship behaviours and turnover intentions. Further, abusive behaviours will indirectly influence employee outcomes through employees' perceptions of organisational support and psychological contract breach. Based on the literature review, the paper proposes a conceptual framework that is useful in explaining the interplay between abusive supervision, psychological contract breach, perceived organisational support, citizenship behaviours and turnover intentions. Finally, the paper outlines steps to advance organisational theory with regard to the effects of abusive supervision on employee outcomes.
\end{abstract}

Keywords: Abusive supervision, Leadership, Psychological Contract Breach, Perceived Organisational Support, Citizenship Behaviours, Turnover Intentions

\section{INTRODUCTION}

Over the past two decades, the role of supervisory leadership has been greatly scrutinised as researchers attempt to unpack how supervisors influence their subordinates' effectiveness in the workplace. While most of the research has focused on the effects of positive leadership behaviour on employee outcomes, such as citizenship behaviours and turnover (Nishii \& Mayer, 2009; Yukl, 2010), an emerging 
stream of research has focused on the effects of abusive supervision and how it impacts subordinates' attitudes and behaviours (Lian, Ferris \& Brown, 2012; Restubog, Scott \& Zagenczyk, 2011; Tepper, 2000, 2007; Tepper, Duffy, Henle \& Lambert, 2006; Tepper, Henle, Lambert, Giacalone \& Duffy, 2008; Tepper, Carr, Breaux, Geider, Hu \& Hua, 2009). Notably, the extant research suggests that abused subordinates have greater turnover intentions, more job dissatisfaction, and increased psychological distress when compared to non-abused subordinates (Keashly, 1998). Clearly, abusive supervision has serious implications for organisations and employees (Aryee, Chen, Sun \& Debrah, 2007; Restubog et al., 2011; Tepper, 2000, 2007; Tepper et al., 2008; Thau \& Mitchell, 2010). The distinct aim of our paper is to propose a conceptual model that integrates literature on abusive supervision, employees' turnover intentions, organisational citizenship behaviours (OCBs) and the mediating and moderating roles of psychological contract breach and perceived organisational support (POS), respectively.

Related to the research on abusive supervision, there is growing interest among organisational researchers in the link between abusive supervision and employees' psychological contract breach (Restubog et al., 2011) and perceptions of organisational support (Kraimer, Seibert, Wayne, Liden \& Bravo, 2011; Wayne, Shore \& Liden, 1997). In a bid to understand the pathways through which abusive supervision impacts employee outcomes, researchers have examined the primary and interactive effects of supervisors' abusive behaviours. Additionally, to help advance the research on abusive supervision, it is vital to examine how abusive behaviours indirectly influence employees' citizenship behaviours and turnover intentions through employees' perceptions of organisational support and psychological contract breach.

Therefore, our conceptual paper has three main objectives. First, in a bid to explain some of the psychological mechanisms through which abusive supervision affects subordinates outcomes, we integrate the extant literature on abusive supervision, psychological contract breach, perceived organisational support, citizenship behaviours and turnover intentions. Second, based on the literature review, we build a conceptual framework that is useful in explaining the linkages between abusive supervision, psychological contract breach, perceived organisational support, citizenship behaviours and turnover intentions. Finally, the paper outlines steps to advance organisational theory in the field of abusive supervision, psychological contract breach, perceived organisational support and employee outcomes. In the next section, we propose a conceptual model through which we attempt to integrate the extant literature on abusive supervision, psychological contract breach, perceived 
organisational support, citizenship behaviours and turnover intentions. Subsequently, based on the model and literature review, we put forward some propositions explaining the possible linkages between abusive supervision, psychological contract breach, perceived organisational support, citizenship behaviours and turnover intentions. Finally, the paper will outline steps to advance organisational theory in the field of abusive supervision, psychological contract breach, perceived organisational support and employee outcomes.

\section{LITERATURE REVIEW AND CONCEPTUAL FRAMEWORK}

\section{Understanding abusive supervision}

Tepper (2000: 178) defines abusive supervision as "subordinates' perceptions of the extent to which their supervisors engage in the sustained display of hostile verbal and nonverbal behaviours, excluding physical contact." Although abusive supervision is a subjective assessment made by subordinates regarding their supervisors' behaviour toward them (Hoobler \& Brass, 2006: 1126), it has been described as a counterproductive behaviour. Further, abusive supervision may manifest in the form of a supervisor publicly ridiculing a subordinate, blaming subordinates for mistakes they did not make, and giving subordinates the silent treatment. The extant research has found that abusive supervision was negatively associated with subordinate frustration, stress, self-esteem, work performance, leader endorsement (Ashforth, 1997), psychological distress, and normative and affective commitment (Tepper, 2000).

Abusive supervision is a counterproductive behaviour (Aryee et al., 2007; Mitchell \& Ambrose, 2007; Restubog et al., 2011; Tepper et al., 2009; Thau, Bennett, Mitchell \& Marrs, 2009). Based on a review by Tepper (2007), abusive supervision was negatively related to a variety of employee attitudes (such as life and job satisfaction, organisational commitment) and behaviours (such as organisational citizenship behaviour, job performance). Aryee and colleagues found that an 'authoritarian leadership style moderated the relationship between supervisors' perceptions of interactional justice and abusive supervision such that the relationship was stronger for supervisors high rather than low in authoritarian leadership style' (Aryee et al., 2007: 191). Furthermore, Aryee and colleagues found that subordinates' perceptions of interactional justice fully mediated the relationship between abusive supervision and work outcomes. Additionally, Restubog and colleagues found that abusive supervision mediated the relationship between aggressive norms and psychological distress and had a direct positive relationship with supervisor-directed 
deviant behaviours. Additionally, those employees who were engaged in relationshiporiented occupations reported greater levels of abusive supervision and psychological distress (Restubog et al., 2011). Therefore, it is vital to examine those psychological mechanisms through which abusive supervision influences employees' outcomes such as citizenship behaviours and turnover intentions.Figure 1 shows the conceptual framework of abusive supervision, employees' OCBs, intention to leave the organisation and mediating and moderating roles of psychological contract breach and perceived organisational support, respectively.

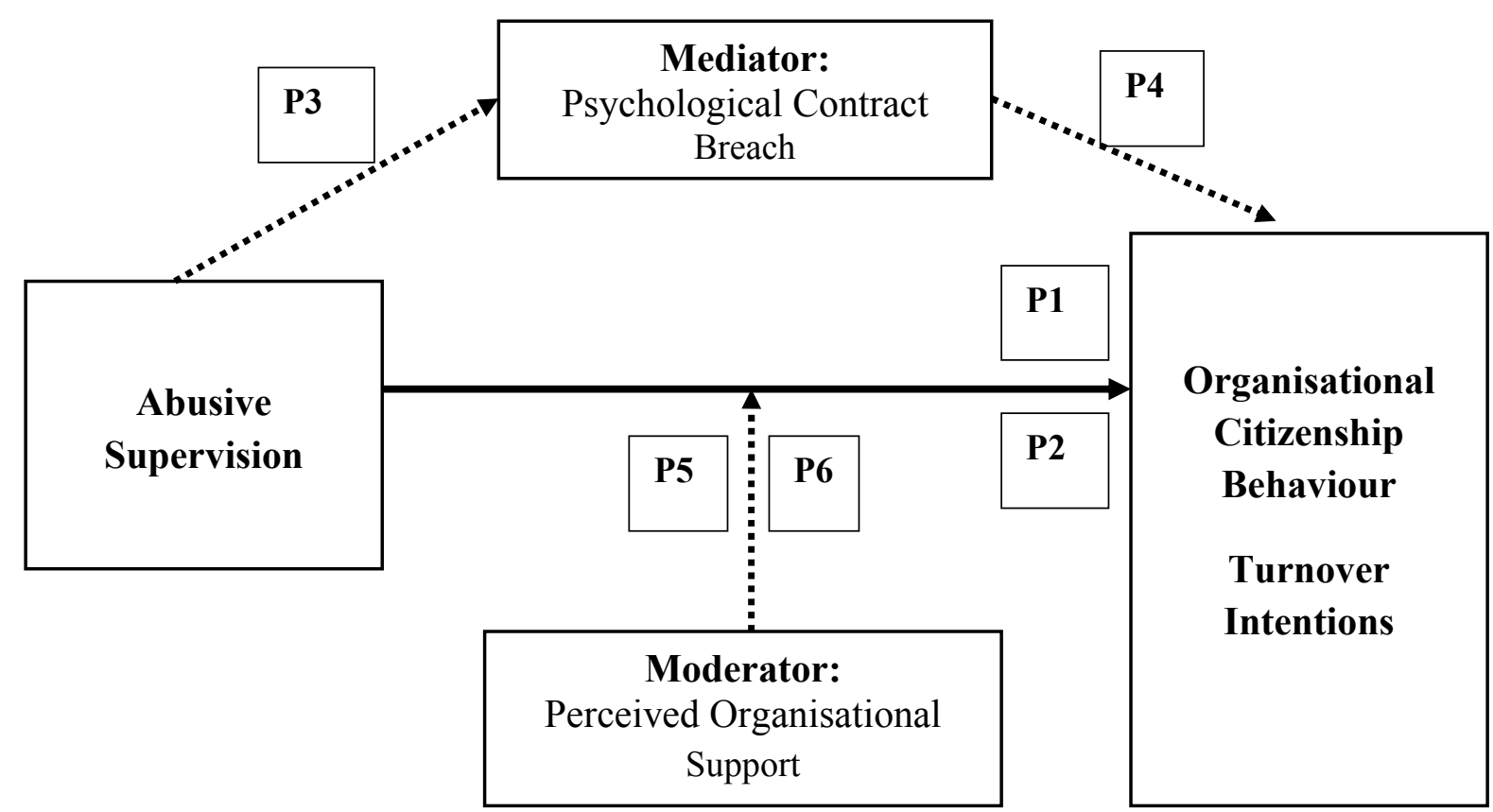

Figure 1 Conceptual Model of Supervisor's Abusive Supervision, OCBs, Turnover Intentions, Psychological Contract and Perceived Organisational Support

\section{Relating abusive supervision to employees' OCBs and turnover intentions}

Organisational citizenship behaviour has been defined as "individual behaviour that is discretionary, not directly or explicitly recognised by the formal reward system, and in aggregate promotes the efficient and effective functioning of the organisation." (Organ, 1988: 4) OCB can be referred to as a set of discretionary workplace behaviours that exceed one's basic job requirements. OCB can also be termed as extra role behaviours that promote organisational effectiveness (Organ, 1988; Robinson \& Morrison, 1995). The importance of OCB in effective organisational functioning is well documented (Podsakoff, Whiting, Podsakoff \& Blume, 2009; Podsakoff, 
MacKenzie, Paine \& Bachrach, 2000; Organ \& Konovsky, 1989; Organ \& Paine, 2001). These behaviours encourage cooperation and association among employees in the workplace and enhance the overall productivity, social environment, stability and managerial productivity of the organisation (Podsakoff et al., 2000; Podsakoff et al., 2009; Organ, 1990a). It has been argued that organisations cannot survive unless individuals engage in these types of behaviours (Organ, 1988). Individuals are believed to engage in OCBs to pay back or reward their organisations for equitable treatment (Robinson \& Morrison, 1995; Organ, 1990b; Organ, 1997). Consequently, OCBs are withheld when employers do not provide adequate outcomes (Robinson \& Morrison, 1995) as a consequence of abusive supervision (Zellers, Tepper \& Duffy, 2002).

Podsakoff and colleagues (2000) summarise the findings from several researchers on possible reasons why OCBs increase organisational performance (Podsakoff et al., 2000). These include: (a) enhancing coworker and managerial productivity (Podsakoff, Ahearne \& MacKenzie, 1997); (b) freeing up resources so they can be used for more productive purposes (Borman \& Motowildo, 1993; Organ, 1988; Podsakoff et al., 1997); (c) reducing the need to devote scarce resources to purely maintenance functions (Organ, 1988; Podsakoff et al., 1997); (d) helping coordinate activities both within and across work groups (Podsakoff et al., 1997); (e) strengthening the organisation's ability to attract and retain the best people by making it a more attractive place to work (George \& Bettenhausen, 1990; Organ, 1988; Podsakoff et al., 1997); (f) increasing the stability of the organisation's performance; and $(\mathrm{g})$ enabling the organisation to more effectively adapt to environmental changes (Podsakoff et al., 2000: 543-546).

There is ample evidence of the effects of leadership style on organisational citizenship behaviours, with most research attesting to the fact that transformational leadership does, in fact, influence such behaviour, although research findings among a sample of petrochemical employees suggested that this relationship might be moderated by the degree of trust subordinates place in their leader (Moorman, 1991; Podsakoff, MacKenzie, Moorman \& Feller, 1990). Empirical research suggests that citizenship behaviours may be withdrawn by an employee in response to negative treatment (Zellers et al., 2002). There is no doubt that employees perceive abusive supervision as a negative and unwanted situation. Abusive supervision represents an imbalance in the social exchange relationship, similar to distributive injustice (Zellers et al., 2002). In order to "get even" with the organisation after an abusive supervisory experience, employees tend to reduce their commitment to the organisation and contribute less in the form of citizenship behaviours (Zellers et al., 2002). 
Research on employee turnover has found that intention to leave the organisation is a reliable predictor of future turnover (Roehling, 1997). Employees' turnover intentions have been of major interest in the management literature. After enduring a negative experience in the workplace (abusive supervision), employees may evaluate the situation and question whether to remain in the employment relationship (Turnley \& Feldman, 1999). It is likely that if they perceive injustice in the relationship after an abusive supervisory experience and contemplate future mistreatment of the same kind, they will look for employment elsewhere. This can also be explained from the social exchange perspective (Blau, 1964). According to the social exchange theory, two parties (i.e. employees and supervisors) are satisfied as long as both sides maintain a mutually beneficial relationship. In the event of an abusive supervisory relationship, an employee's trust in the fulfilment of future exchanges is severely damaged, and the negative treatment denies valued benefits. As a result, they may believe that it is important to look for alternative employment opportunities in order to obtain valued benefits in the future. The actual turnover of employees following abusive supervision may affect organisational performance. Employee turnover is costly to the organisation (Roehling, 1997). From the organisation's perspective, it takes substantial time, money and effort to recruit new employees, and such loss often disrupts regular business operations and fosters low workforce morale (Kacmar, Andrews, Van Rooy, Steilberg \& Cerrone, 2006; Zhao, Wayne, Glibkowski \& Bravo, 2007). Actual turnover of employees can be viewed as a tangible impact of abusive supervision on the organisation. It is thus predicted that:

Proposition 1: A supervisor's abusive supervision will be negatively related to an employee's citizenship behaviours.

Proposition 2: A supervisor's abusive supervision will be positively related to an employee's intention to leave the organisation.

\section{Mediating effects of psychological contract breach}

Several aspects of the employment relationship are unwritten or are not formally established between the employee and the employer (Middlemiss, 2011; Rousseau, 1989). The unwritten or informal aspects of the employment relationship can be based on employees' perceptions and interpretations of the communications regarding promises made by the employer (Rousseau, 1989, 1995). This portion of the employment contract is in the minds of the employees and is defined as the psychological contract (Rousseau, 1989). The basic nature of the contract is a "reciprocal obligation," as the employees expect to receive benefits in exchange for their contribution to the organisation. 
Psychological contract breach has been defined as the cognitive perception that an employee has not received everything that was formally or informally promised by the organisation (Morrison \& Robinson, 1997). Psychological contract breach is related to a range of undesirable employee attitudes and behaviours. For example, psychological contract breach is negatively associated with an employee's trust in management (Deery, Iverson \& Walsh, 2006), job satisfaction (Raja, Johns \& Ntalianis, 2004), intentions to remain with the organisation (Lo \& Aryee, 2003; Raja et al., 2004; Robinson, 1996; Suazo, Turnley \& Mai-Dalton, 2005; Turnley \& Feldman, 1998, 1999, 2000), employee performance (Restubog, Bordia \& Tang, 2007), citizenship behaviours (Kickul, Neuman, Parker \& Finkl, 2001; Restubog et al., 2007; Suazo \& Stone-Romero, 2011), civic virtue behaviours (Chambel \& Alcover, 2011), and employee commitment (Johnson \& O'Leary-Kelly, 2003; Raja et al., 2004; Suazo et al., 2005); while it is positively associated with workplace deviant behaviours (Bordia, Restubog \& Tang, 2008), employee neglect of job duties (Turnley \& Feldman, 1998, 1999, 2000), job burnout (Chambel \& Oliveira-Cruz, 2010), employee cynicism about their employer (Johnson \& O'Leary-Kelly, 2003), higher absenteeism (Deery et al., 2006; Johnson \& O'Leary-Kelly, 2003) and revenge cognitions (Ahmed, Bordia \& Restubog, 2007; Bordia et al., 2008).

After a psychological contract breach, employees evaluate the situation and question whether to remain in the employment relationship (Turnley \& Feldman, 1999). If employees perceive high imbalance in the relationship after psychological contract breach and contemplate future mistreatment of the same kind, it is likely that they will look for employment elsewhere and reduce their citizenship behaviour. This can also be explained from the social exchange perspective. In other words, employees who are subjected to abusive supervision may believe that it is important to look for alternative employment opportunities in order to obtain valued benefits in the future and to reduce citizenship behaviour to 'get even' with the organisation. Robinson and colleagues found that perception of psychological contract breach is negatively associated with the intention to remain with the organisation (Robinson, Kraatz \& Rousseau, 1994: Robinson, 1996). Prior studies have also suggested that psychological contract breach is negatively related to employees' affective commitment and OCBs (Lester, Turnley, Bloodgood \& Bolino, 2002; Raja et al., 2004) and positively related to employees' intentions to quit their jobs (Lo \& Aryee, 2003; Raja et al., 2004; Robinson et al., 1994; Suazo et al., 2005). A meta-analysis indicated that perceived psychological contract breach was positively related to employees' turnover intentions (Zhao et al., 2007). If employees evaluate the situation, perceive high imbalance in the relationship after psychological contract 
breach and contemplate future mistreatment of the same kind, we predict that employees will look for employment elsewhere and reduce OCBs. Thus, psychological contract breach is likely to mediate the relationship between a supervisor's abusive supervision and an employee's intention to leave the organisation and OCBs.

Proposition 3: An employee's psychological contract breach will mediate the relationship between a supervisor's abusive supervision and an employee's intent to leave the organisation.

Proposition 4: An employee's psychological contract breach will mediate the relationship between a supervisor's abusive supervision and an employee's OCBs.

\section{Moderating effects of perceived organisational support}

Perceived organisational support (POS) can be defined as employees' perceptions that their employing organisation cares about their well-being, values their contributions towards the organisation's success, and in future is likely to assist them if needed to continue their employment and to effectively manage their stress-related issues (Eisenberger, Huntington, Hutchinson \& Sowa,1986; Rhoades \& Eisenberger, 2002: 698). According to the organisational support theory, the development of POS stems from employees' perceptions of procedural fairness, interactional justice and remuneration (Rhoades \& Eisenberger, 2002). An example of a POS is the designation of organisations as supportive when the organisations provide their employees with required skills training or any other assistance. Employees' POS can also be defined by an organisation's commitment towards its employees (Makanjee, Hartzer \& Uys, 2006). Organisational researchers have also suggested two other perceived supports within the organisational context. These are perceived supervisor support (PSS), where employees believe that their supervisors or managers are supportive, value their contributions and care for employees' well-being; and perceived co-worker support (PCS), which can be defined as employees' perceptions of receiving support from caring coworkers (Kottke \& Sharafinski, 1988). The theoretical basis of POS is the social exchange theory, which suggests that employees will be loyal and contribute towards the organisation's success if they receive positive, fair and caring treatment from the organisation (Blau, 1964; Levinson, 1965). Thus, POS represents employees' perspectives of the exchange relationship between the employee and the employer (Settoon, Bennett \& Liden, 1996). Based on the reciprocity norm inherent in the social exchange theory, POS creates perceived obligations among employees to care about 
the organisation's well-being and contribute and support the organisation in achieving its objectives (Eisenberger, Armeli, Rexwinkel, Lynch \& Rhoades, 2001).

Over the last two decades, POS has received attention from organisational researchers, and it has become an important predictor for a number of employee attitudes and behaviours, in addition to employee well-being. A meta-analysis conducted by Rhoades and Eisenberger (2002) on more than 70 empirical studies examined the associations between POS and its outcomes. Results of the metaanalyses revealed POS to be positively associated with organisational commitment, job satisfaction, positive mood at work, job involvement, in-role performance, extrarole performance towards the organisation, and desire to remain with the organisation. Based on a large Canadian sample ( $n=24000$ employees), Robertson Blackmore and colleagues have suggested that lack of support from supervisors and co-workers is a significant predictor of stress and depression among employees (Wayne, Shore, Bommer \& Tetrick, 2002; Blackmore, Stansfeld, Weller, Munce, Zagorski \& Stewart, 2007). Similarly, perception of lack of organisational support was found to be positively associated with job stress among Hispanic employees (Rodriguez-Calcagno \& Brewer, 2005), workplace deviant behaviour towards the organisation (Liao, Joshi $\&$ Chuang, 2004), and employee job burnout (Jawahar, Stone \& Kisamore, 2007). Employees' POS was also found to be positively related to job satisfaction (Shore \& Tetrick, 1991; Eisenberger, Cummings, Armeli \& Lynch, 1997), affective organisational commitment (Eisenberger, Fasolo \& Davis-LaMastro, 1990; Guzzo, Noonan \& Elron, 1994; Settoon et al., 1996; Shore \& Tetrick, 1991), customer commitment (Vandenberghe, Bentein, Michon, Chebat, Tremblay \& Flis, 2007), employees' in-role and extra-role behaviours (Rhoades \& Eisenberger, 2002; Wayne et al., 1997; Eisenberger et al., 1990, 1986), reduced absenteeism (Eisenberger et al., 1990, 1986), and increased intention to remain with the organisation (Wayne et al., 1997). Based on the above discussion, it can be argued that employees' POS influences employees' attitudinal and behavioural outcomes. In the proposed model of abusive supervision and employees' behavioural and attitudinal outcomes, POS is suggested to act as a moderator, influencing the relationship between abusive supervision and employees' OCBs and turnover intentions. As POS creates selfobligations among employees to work harder towards achieving organisational goals, it is predicted that after an abusive supervision experience, employees may engage in extra role behaviour and remain with the organisation due to POS. Hence, it is suggested that:

Proposition 5: Perceived organisational support (POS) will moderate the relationship between a supervisor's abusive supervision and an employee's 
OCBs, such that the relationship between abusive supervision and OCBs will be stronger when POS is high than when it is low.

Proposition 6: Perceived organisational support (POS) will moderate the relationship between a supervisor's abusive supervision and an employee's intention to leave the organisation, such that the relationship between abusive supervision and intention to leave will be stronger when POS is low than when it is high.

\section{CONCLUSION}

Following a brief literature review, this paper proposed a conceptual framework that is useful for explaining the linkages between psychological contract, perceived organisational support, supervisor behaviours, citizenship behaviours and turnover intentions. Specifically, the paper examined the interplay between psychological contract, perceived organisational support, supervisor behaviours, citizenship behaviours and turnover intentions. The proposed conceptual model has the potential to help management developers design appropriate leadership development programs that will help supervisors adjust their leadership styles to fit specific contextual factors and to minimise turnover intentions among employees. Furthermore, the conceptual framework may act as a trigger for credible research questions that will in turn spur more researchers to study how those supervisor behaviours and organisational support systems discussed herein potentially influence psychological contract, citizenship behaviours and turnover intentions.

To advance organisational theory regarding psychological contract, perceived organisational support, supervisor behaviours, citizenship behaviours and turnover intentions, this paper proposes several steps. First, future research should consciously integrate supervisor behaviours in comprehensive organisational studies that examine how leadership is manifested in organisations. Second, researchers should design broader studies which build on existing studies that have examined supervisor behaviours and organisational support systems, so that we better understand how they influence organisational effectiveness. Finally, although it is not included in the current conceptual model, this paper acknowledges the need for future research models to incorporate dispositional characteristics, including personality traits, and cognitive abilities within a larger conceptual framework of supervisor behaviours and organisational support systems, so that we may better understand how they influence organisational effectiveness. In conclusion, this paper has proposed a conceptual framework for examining the interplay between psychological contract, perceived organisational support, supervisor behaviours, citizenship behaviours and turnover 
intentions. We encourage organisational researchers to test out our research model and the accompanying propositions to determine if there are significant relationships among the proposed linkages between psychological contract, perceived organisational support, supervisor behaviours, citizenship behaviours and turnover intention.

\section{REFERENCES}

Ahmed, E., Bordia, P., \& Restubog, S. L. D. (2007). Revenge seeking and forgiveness: employees' cognitive responses after a psychological contract breach. Paper presented at the 9th South Asian Management Forum, Dhaka, Bangladesh.

Aryee, S., Chen, Z., Sun, L. Y., \& Debrah, Y. A. (2007). Antecedents and outcomes of abusive supervision: Test of a trickle-down model. Journal of Applied Psychology, 92, 191-201. http://dx.doi.org/10.1037/0021-9010.92.1.191

Ashforth, B. (1997). Petty tyranny in organizations: A preliminary examination of antecedents and consequences. Canadian Journal of Administrative Sciences, 14, 126-140. http://dx.doi.org/10.1111/j.1936-4490.1997.tb00124.x

Blackmore, R. E., Stansfeld, S. A., Weller, I., Munce, S., Zagorski, B. M., \& Stewart, D. E. (2007). Major depressive episodes and work stress: Results from a national population survey. American Journal of Public Health, 97(11), 2088-2093. http://dx.doi.org/10.2105/AJPH.2006.104406

Blau, P. M. (1964). Exchange and power in social life. New York, NY: Wiley and Sons.

Bordia, P., Restubog, S. L. D., \& Tang, R. L. (2008). When employees strike back: Investigating mediating mechanisms between psychological contract breach and workplace deviance. Journal of Applied Psychology, 93(5), 1104-1117. http://dx.doi.org/10.1037/0021-9010.93.5.1104

Borman, W. C. \& Motowildo, S. J. (1993). Expanding the criterion domain to include elements of extra role performance. In N. Schmitt \& W. C. Borman (Eds.), Personnel Selection in Organisations (pp. 71-98). San Francisco: Jossey-Bass.

Chambel, M. J. \& Alcover, C. M. (2011). The psychological contract of call-centre workers: Employment conditions, satisfaction and civic virtue behaviours. Economic and Industrial Democracy, 32(1), 115-134. http://dx.doi.org/10.1177/0143831X10376421

Chambel, M. J. \& Oliveira-Cruz, F. (2010). Breach of psychological contract and the development of burnout and engagement: A longitudinal study among soldiers on a peace-keeping mission. Military Psychology, 22, 110-127. 
Deery, S. J., Iverson, R. D., \& Walsh, J. T. (2006). Toward a better understanding of psychological contract breach: A study of customer service employees. Journal of Applied Psychology, 91(1), 166-175. http://dx.doi.org/10.1037/00219010.91.1.166

Eisenberger, R., Armeli, S., Rexwinkel, B., Lynch, P. D., \& Rhoades, L. (2001). Reciprocation of perceived organizational support. Journal of Applied Psychology, 86, 42-51. http://dx.doi.org/10.1037/0021-9010.86.1.42

Eisenberger, R., Cummings, J., Armeli, S., \& Lynch, P. (1997). Perceived organizational support, discretionary treatment, and job satisfaction. Journal of Applied Psychology, 82, 812-820. http://dx.doi.org/10.1037//0021-9010.82.5.812

Eisenberger, R., Huntington, R., Hutchinson, S., \& Sowa, D. (1986). Perceived organizational support. Journal of Applied Psychology, 71, 500-507.

Eisenberger, R., Fasolo, P., \& Davis-LaMastro, V. (1990). Perceived organizational support and employee diligence, commitment, and innovation. Journal of Applied Psychology, 75, 51-59. http://dx.doi.org/10.1037//0021-9010.75.1.51

George, J. M. \& Bettenhausen, K. (1990). Understanding pro-social behaviour, sales performance, and turnover: A group level analysis in a service context. Journal of Applied Psychology, 75, 698-709. http://dx.doi.org/10.1037//00219010.75 .1 .51

Guzzo, R. A., Noonan, K. A., \& Elron, E. (1994). Expatriate managers and the psychological contract. Journal of Applied Psychology, 79, 617-626. http://dx.doi.org/10.1037//0021-9010.79.4.617

Hoobler, J. M. \& Brass, D. J. (2006). Abusive supervision and family undermining as displaced aggression. Journal of Applied Psychology, 91, 1125-1133. http://dx.doi.org/10.1037/0021-9010.91.5.1125

Jawahar, I. M., Stone, T. H., \& Kisamore, J. L. (2007). Role conflict and burnout: The direct and moderating effects of political skill and perceived organizational support on burnout dimensions. International Journal of Stress Management, 14(2), 142-159. http://dx.doi.org/10.1037/1072-5245.14.2.142

Johnson, J. L. \& O'Leary-Kelly, A. M. (2003). The effects of psychological contract breach and organizational cynicism: Not all social exchange violations are created equal. Journal of Organizational Behavior, 24(5), 627-647. http://dx.doi.org/10.1002/job.207

Kacmar, K. M., Andrews, M. C., Van Rooy, D. L., Steilberg, R. C., \& Cerrone, S. (2006). Sure everyone can be replaced but at what cost? Turnover as a predictor of unit-level performance. Academy of Management Journal, 49(1), 133-144. http://dx.doi.org/10.5465/AMJ.2006.20785670 
Keashly, L. (1998). Emotional abuse in the workplace: Conceptual and empirical issues. Journal of Emotional Abuse, 1, 85-117. http://dx.doi.org/10.1300/J135v01n01_05

Kickul, J., Neuman, G., Parker, C., \& Finkl, J. (2001). Settling the score: The role of organizational justice in the relationship between psychological contract breach and anticitizenship behavior. Employee Responsibilities and Rights Journal, 13(2), 77-93.

Kottke, J. L. \& Sharafinski, C. E. (1988). Measuring perceived supervisory and organizational support. Educational and Psychological Measurement, 48, 10751079. http://dx.doi.org/10.1177/0013164488484024

Kraimer, M. L., Seibert, S. E., Wayne, S. J., Liden, R. C., \& Bravo, J. (2011). Antecedents and outcomes of organizational support for development: the critical role of career opportunities. Journal of Applied Psychology, 96, 485-500. http://dx.doi.org/10.1037/a0021452

Lester, S. W., Turnley, W. H., Bloodgood, J. M., \& Bolino, M. C. (2002). Not seeing eye to eye: Differences in supervisor and subordinate perceptions of and attributions for psychological contract breach. Journal of Organizational Behavior, 23(1), 39-56. http://dx.doi.org/10.1002/job.126

Levinson, H. (1965). Reciprocation: The relationship between man and organization. Administrative Science Quarterly, 9, 370-390.

Liao, H., Joshi, A., \& Chuang, A. (2004). Sticking out like a sore thumb: Employee dissimilarity and deviance at work. Personnel Psychology, 57, 969-1000. http://dx.doi.org/10.1111/j.1744-6570.2004.00012.x

Lian, H., Ferris, D. L., \& Brown, D. J. (2012). Does power distance exacerbate or mitigate the effects of abusive supervision? It depends on the outcome. Journal of Applied Psychology, 97(1), 485-500. http://dx.doi.org/10.1037/a0024610

Lo, S. \& Aryee, S. (2003). Psychological Contract breach in a chinese context: An integrative approach. Journal of Management Studies, 40(4), 1005-1020. http://dx.doi.org/10.1111/1467-6486.00368

Makanjee, R. C., Hartzer, Y., \& Uys, I. (2006). The effect of perceived organizational support on organizational commitment of diagnostic imaging radiographers, Radiography, 12(2), 118-126. http://dx.doi.org/10.1016/j.radi.2005.04.005

Middlemiss, S. (2011). The psychological contract and implied contractual terms: Synchronous or asynchronous models? International Journal of Law and Management, 53(1), 32-50. http://dx.doi.org/10.1108/17542431111111872 
Mitchell, M. S. \& Ambrose, M. L. (2007). Abusive supervision and workplace deviance and the moderating effects of negative reciprocity beliefs. Journal of Applied Psychology, 92, 1159-1168. http://dx.doi.org/10.1037/00219010.92.4.1159

Moorman, R. H. (1991). Relationship between organizational justice and organizational citizenship behavior: Do fairness perceptions influence employee citizenship? Journal of Applied Psychology, 76, 845-855. http://dx.doi.org/10.1037//0021-9010.76.6.845

Morrison, E. W. \& Robinson, S. L. (1997). When employees feel betrayed: A model of how psychological contract violation develops. The Academy of Management Review, 22(1), 226-256. http://dx.doi.org/10.2307/259230

Nishii, L. H. \& Mayer, D. M. (2009). Do inclusive leaders help to reduce turnover in diverse groups? The moderating role of leader-member exchange in the diversity to turnover relationship. Journal of Applied Psychology, 94(6), 1412-1426. http://dx.doi.org/10.1037/a0017190

Organ, D. W. (1988). Organisational citizenship behaviour: The good soldier syndrome. Lexington, Massachusetts: Lexington Books.

Organ, D. W. (1990a). The motivational basis of organisational citizenship behaviour. In B. M. Staw \& L. L. Cummings (Eds.), Research in organisational behaviour, 12 (pp. 43-72). Greenwich, Connecticut: JAI Press.

Organ, D. W. (1990b). The subtle significance of job satisfaction. Clinical Laboratory Management Review, 4, 94-98.

Organ, D. W. (1997). Organizational citizenship behavior: It's construct clean-up time. Human Performance, 10, 85-97. http://dx.doi.org/10.1207/s15327043hup1002_2

Organ, D. W. \& Konovsky, M. (1989). Cognitive versus affective determinants of organisational citizenship behaviour. Journal of Applied Psychology, 74, 157-164. http://dx.doi.org/10.1037/0021-9010.74.1.157

Organ, D. W. \& Paine, J. B. (2001). A new kind of performance for industrial and organisational psychology: Recent contributions to the study of organisational citizenship behaviour. In C. Cooper \& I. Robertson (Eds.), Organizational psychology and development: A reader for students and practitioners, 14 (pp. 337-368), Chichester, England: John Wiley \& Sons Ltd.

Podsakoff, P. M., MacKenzie, S. B., Moorman, R. H., \& Feller, R. (1990). Transformational leader behaviors and their effects on followers' trust in leader, satisfaction, and organizational citizenship behaviour. Leadership Quarterly, 1, 107-142. http://dx.doi.org/10.1016/1048-9843(90)90009-7 
Podsakoff, P. M., Ahearne, M., \& MacKenzie, S. B. (1997). Organizational citizenship behaviour and the quantity and quality of work group performance. Journal of Applied Psychology, 82, 262-270. http://dx.doi.org/10.1037/00219010.82 .2 .262

Podsakoff, P. M., MacKenzie, S. B., Paine, J. B., \& Bachrach, D. G. (2000). Organizational citizenship behaviors: A critical review of the theoretical and empirical literature and suggestions for future research. Journal of Management, 26, 513-563. http://dx.doi.org/10.1177/014920630002600307

Podsakoff, N. P., Whiting, S. W., Podsakoff, P. M., \& Blume, B. D. (2009). Individual- and organizational-level consequences of organizational citizenship behaviors: A meta-analysis. Journal of Applied Psychology, 94, 122-141. http://dx.doi.org/10.1037/a0013079

Raja, U., Johns, G., \& Ntalianis, F. (2004). The impact of personality on psychological contracts. The Academy of Management Journal, 47(3), 350-367. http://dx.doi.org/10.2307/20159586

Restubog, S. L. D., Bordia, P., \& Tang, R. L. (2007). Behavioural outcomes of psychological contract breach in a non-western culture: The moderating role of equity sensitivity. British Journal of Management, 18(4), 376-386. http://dx.doi.org/10.1111/j.1467-8551.2007.00531.x

Restubog, S. L. D., Scott, K. L., \& Zagenczyk, T. J. (2011). When distress hits home: The role of contexual factors and psychological distress in predicting employee's responses to abusive supervision. Journal of Applied Psychology, 96(4), 713-729.

Rhoades, L. \& Eisenberger, R. (2002). Perceived organizational support: A review of the literature. Journal of Applied Psychology, 87, 698-714. http://dx.doi.org/10.1037//0021-9010.87.4.698

Robinson, S. L. (1996). Trust and breach of the psychological contract. Administrative Science Quarterly, 41(4), 574-599. http://dx.doi.org/10.2307/2393868

Robinson, S. L., Kraatz, M. S., \& Rousseau, D. M. (1994). Changing obligations and the psychological contract: A longitudinal study. The Academy of Management Journal, 37, 137-152. http://dx.doi.org/10.2307/256773

Robinson, S. L. \& Morrison, E. W. (1995). Psychological contracts and OCB: The effect of unfulfilled obligations on civic virtue behaviour. Journal of Organizational Behavior, 16, 289-298. http://dx.doi.org/10.1002/job.4030160309

Rodriguez-Calcagno, M. \& Brewer, E. W. (2005). Job stress among Hispanic professionals. Hispanic Journal of Behavioural Sciences, 27(4), 504-516. http://dx.doi.org/10.1177/0739986305280691 
Roehling, M. V. (1997). The origins and early development of the psychological contract construct. Journal of Management History, 3(2), 204-217. http://dx.doi.org/10.1108/13552529710171993

Rousseau, D. M. (1989). Psychological and implied contracts in organizations. Employee Responsibilities and Rights Journal, 2, 121-139. http://dx.doi.org/10.1007/BF01384942

Rousseau, D. M. (1995). Psychological contracts in organizations: Understanding written and unwritten agreements. Thousand Oaks, CA: Sage.

Shore, L. M. \& Tetrick, L. E. (1991). A construct validity study of the survey of perceived organizational support. Journal of Applied Psychology, 76, 637-643. http://dx.doi.org/10.1037//0021-9010.76.5.637

Settoon, R. P., Bennett, N., \& Liden, R. C. (1996). Social exchange in organizations: Perceived organizational support, leader-member exchange, and employee reciprocity. Journal of Applied Psychology, 81, 219-227. http://dx.doi.org/10.1037//0021-9010.81.3.219

Suazo. M. M., Turnley, W. H., \& Mai-Dalton, R. R. (2005). The role of perceived violation in determining employee's reactions to psychological contract breach. Journal of Leadership and Organizational Studies, 12(1), 24-36.

Suazo, M. M. \& Stone-Romero, E. F. (2011). Implications of psychological contract breach: A perceived organizational support perspective. Journal of Managerial Psychology, 26(5), 366-382. http://dx.doi.org/10.1108/02683941111138994

Tepper, B. J. (2000). Consequences of abusive supervision. Academy of Management Journal, 43, 178-190. http://dx.doi.org/10.2307/1556375

Tepper, B. J. (2007). Abusive supervision in work organizations: review, synthesis and research agenda. Journal of Management, 33, 261-289. http://dx.doi.org/10.1177/0149206307300812

Tepper, B. J., Carr, J. C., Breaux, D. M., Geider, S., Hu, C., \& Hua, W. (2009). Abusive supervision, intentions to quit, and employees' workplace deviance: A power/dependence analysis. Organizational Behavior and Human Decision Processes, 109, 156-167.

Tepper, B. J., Duffy, M. K., Henle, C. A., \& Lambert, L. S. (2006). Procedural injustice, victim precipitation, and abusive supervision. Personnel Psychology, 59, 101-123. http://dx.doi.org/10.1111/j.1744-6570.2006.00725.x

Tepper, B. J., Henle, C. A., Lambert, L. S., Giacalone, R. A., \& Duffy, M. K. (2008). Abusive supervision and subordinates' organizational deviance. Journal of Applied Psychology, 93, 721-732. 
Thau, S., Bennett, R. J., Mitchell, M. S., \& Marrs, M. B. (2009). How management style moderates the relationship between abusive supervision and workplace deviance: An uncertainty management theory perspective. Organizational Behavior and Human Decision Processes, 108, 79-92. http://dx.doi.org/10.1016/j.obhdp.2008.06.003

Thau, S. \& Mitchell, M. S. (2010). Self-gain or self-regulation impairment? Tests of competing explanations of the supervisor abuse and employee deviance relationship through perceptions of distributive justice. Journal of Applied Psychology, 95(6), 1009-1031. http://dx.doi.org/10.1037/a0020540

Turnley, W. H. \& Feldman, D. C. (1998). Psychological contract violations during corporate restructuring. Human Resource Management, 37(1), 71-83. http://dx.doi.org/10.1002/(SICI)1099-050X(199821)37:1\%3C71::AIDHRM7\%3E3.0.CO;2-S

Turnley, W. H. \& Feldman, D. C. (1999). The impact of psychological contract violations on exit, voice, loyalty and neglect. Human Relations, 52, 895-922. http://dx.doi.org/10.1177/001872679905200703

Turnley, W. H. \& Feldman, D. C. (2000). Re-examining the effects of psychological contract violations: Unmet expectations and job dissatisfaction as mediators. Journal of Organizational Behavior, 21(1), 25-42. http://dx.doi.org/10.1002/(SICI)1099-1379(200002)21:1\%3C25::AIDJOB2\%3E3.0.CO;2-Z

Vandenberghe, C., Bentein, K., Michon, M., Chebat, J., Tremblay, M., \& Flis, J. (2007). An examination of the role of perceived support and employee commitment it employee-customer encounters. Journal of Applied Psychology, 92(4), 1177-1187. http://dx.doi.org/10.1037/0021-9010.92.4.1177

Wayne, S. J., Shore, L. M., Bommer, W., \& Tetrick, L. (2002). The role of fair treatment and rewards in perceptions of organizational support and leadermember exchange. Journal of Applied Psychology, 87, 590-598. http://dx.doi.org/10.1037/0021-9010.87.3.590

Wayne, S. J., Shore, L. M., \& Liden, R. C. (1997). Perceived organizational support and leader-member exchange: A social exchange perspective. Academy of Management Journal, 40, 82-111. http://dx.doi.org/10.2307/257021

Yukl, G. A. (2010). Leadership in organizations (7th ed.). Upper Saddle River, NJ: Prentice Hall.

Zellers, K. L., Tepper, B. J., \& Duffy, M. K. (2002). Abusive supervision and subordinates' organizational citizenship behavior. Journal of Applied Psychology, 87(6), 1068-1076. 
Zhao, H. A. O., Wayne, S. J., Glibkowski, B. C., \& Bravo, J. (2007). The impact of psychological contract breach on work related outcomes: A meta analysis. Personnel Psychology, 60(3), 647-680. http://dx.doi.org/10.1111/j.17446570.2007.00087.x 